\title{
Phytochemical Investigation of Dipcadi Ervthraeum
}

\author{
HADI A. AL-NAJJAR, Ph.D. \\ The Department of Pharmacy, College of Health Sciences, Public Authority for Applied Education and Training (PAAET), \\ Kuwait
}

\begin{abstract}
Background: Dipcadi erythraeum is a wild edible species belonging to family Asparagaceae and commonly used in folk medicine.

Aim of Study: This study was designed to carry out a detailed phytochemical screening of the active constituents in the bulbs, stems, leaves and flowers of Dipcadi erythraeum.

Material and Methods: Phytochemical screening were done for Dipcadi erythraeum plant after collection from Kabd and Ahmadi deserts in Kuwait during spring 2005.

Results: Dipcadi erythraeum was reported to contain high glycosides levels, but from the phytochemical screening it showed no significant levels. The presence of flavonoids and starchy carbohydrates was noticeable.

Conclusion: The results of the current paper could serve as a starting point for further investigation of the flavanoidal contents of the Dipcadi erythraeum plant.
\end{abstract}

Key Words: Dipcadi erythracum - Flavonoids - Glycosides - Liliaceae.

\section{Introduction}

DIPCADI Medik is a genus of bulbous flowering plants which is recently belonging to the subfamily Scilloideae of Asparagaceae family. It contains about 40 species, commonly distributed in different areas such as Southern Europe, most area of Africa, the Middle East and also East to South Asia [1].

South Africa has the greatest diversity of distribution as contains 13 species [2] followed by India which contains 9 species [3].

In Egypt, the genus Dipcadi is also a member of family Hyacinthaceae and is found in two

Correspondence to: Dr. Hadi A. Al-Najjar, The Department of Pharmacy, College of Health Sciences, Public Authority for Applied Education and Training (PAAET), Kuwait species: Dipcadi erythraeum (D. erythraeum) and Dipcadi unifolium Bak [4] .

The genera of this family were initially included within Liliaceae S.L. [5].

D.erythraeum is a wild medicinal plant. Its bulb and capsule are edible especially in Pakistan [6].

In Bahrain, the leaves can be used as a laxative and as an ointment for wounds treatment [7].

Dipcadi ervthraeum is known as the desert lorowan bell of Kuwait, there are probably five species found in Kuwait and Saudi Arabia. This plants usually has 2-3 leave, that lye on the sand surface moving around by the wind forming circular tracks on the sand $[8,9]$, as shown in Figs. $(1,2)$.

Dipcadi erythraeum is observed to be found in rocky and gravelly habitats where rainwater are collected for some days. Despite, the leaves are narrowly linear, the flowers have green color. Flowers and fruits appear during the months from August to September. Dipcadi erythraeum is a medicinal plant which has different important folk uses. Although the bulbs and capsules are raw, they can be eaten during the famine [10]

Rizk $[11,12,13]$ had reported on Dipcadi ervthreum constituents. In this report Dipcadi ervthreum was tested for the presence of active constituents after doing a through background search in the published literature.

No previous phytochemical studies have been reported for kuwaits D.erythraeum. The present study aimed to design a detailed phytochemical screening of the active constituents in the bulbs, stems, leaves and flowers of Dipcadi erythracum. 

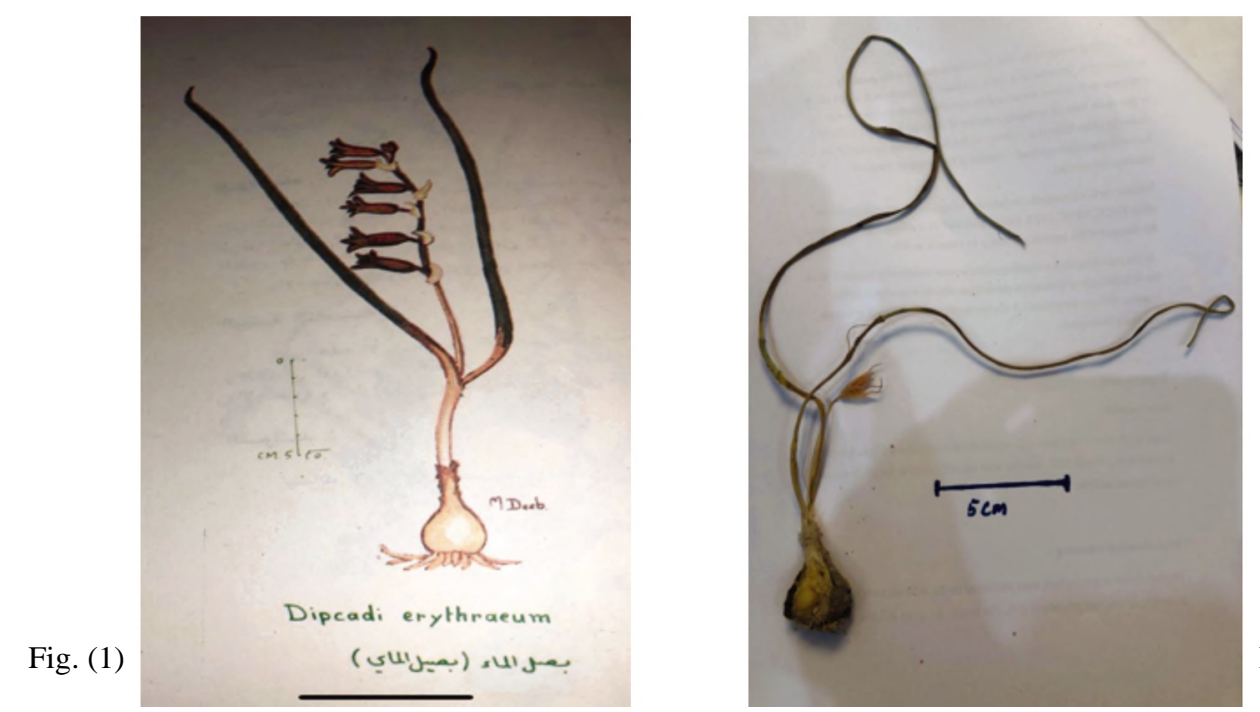

Fig. (2)

Figs. (1,2): Phytochemical screening for Dipcadi erythraeum plant.

\section{Material and Methods}

Experimental:

\section{Plant material:}

Plant material was collected from Kabd and Ahmadi deserts in Kuwait during spring 2005. Voucher specimens were deposited at Kuwait university herbarium after authentication by Dr. KT. Methew the herbarium Keeper.

Phytochemical screening were done as in Bain \& Tuner [14].

\section{Results}

\section{Macroscopy:}

A perennial plant, as shown in Fig. (2) up to $20 \mathrm{~cm}$ tall with a grey, ovate conical bulb. $3-4 \mathrm{~cm}$ long: Leaves narrow linear. In florescence one sided raceme with 5-12 flowers, $12-55 \mathrm{~mm}$ long: Pedicel very short capsule large. Deeply 3-grooved. Seeds plano convex ovate in outline.

\section{Discussion}

The genus Dipcadi is recently belonging to the subfamily Scilloideae of the family Asparagaceae. It is reported mainly from Africa, peninsular India, Madagascar, and also neighboring Pakistan. Ten species of this genus are reported, of which D. erythraeum Webb \& Berthel is distributed in India as well as in different tropical regions of the world such as the Canary Islands, Arabia, Egypt, and Saudi Arabia [15]

As mentioned before, in addition to the use of the leaves as laxative and as an ointment for wounds [7], the whole plant can be used for treatment of cough, biliousness, diabetes, urinary and discharge.
Phytochemical screening of some Dipcadi species reported tannins, alkaloids, flavonoids, and saponins presence $[16,17,18]$.

El-Shabrawy et al., reported that from the D. erythraeum whole plant defatted aqueous methanol extract, two flavonol aglycones (kaempferol and quercetin), one flavonol glycoside (quercetin 3-Orutinoside-7-O- $\alpha$-rhamnopyranoside), and four $\mathrm{C}$ glycosyl flavones (vitexin, isovitexin, orientin, and isoorientin) can be isolated [6] .

Table (1): Phytochemical screening test.

\begin{tabular}{|c|c|c|c|}
\hline Test For: & Bulb & Stem and Leaf & Flower \\
\hline $\begin{array}{l}\text { Sterols \& triterpenes: } \\
\quad \text { Libermanns test }\end{array}$ & $++\mathrm{ve}$ & $+\mathrm{ve}$ & $+\mathrm{ve}$ \\
\hline $\begin{array}{l}\text { Sterols \& triterpenes: } \\
\text { Libermanns test } \\
\text { Salkwishki test }\end{array}$ & $\begin{array}{l}\text { ++ve } \\
++\mathrm{ve}\end{array}$ & $\begin{array}{l}+\mathrm{ve} \\
+\mathrm{ve}\end{array}$ & $\begin{array}{l}+\mathrm{ve} \\
+\mathrm{ve}\end{array}$ \\
\hline $\begin{array}{l}\text { Alkaloids or nitrogenous } \\
\text { bases: } \\
\text { Dragenor ffs reagent } \\
\text { Wagner's reagent } \\
\text { Mayer's reagent }\end{array}$ & $\begin{array}{l}+\mathrm{ve} \\
+\mathrm{ve} \\
-\mathrm{ve}\end{array}$ & $\begin{array}{l}-\mathrm{ve} \\
-\mathrm{ve} \\
-\mathrm{ve}\end{array}$ & $\begin{array}{l}-\mathrm{ve} \\
-\mathrm{ve} \\
-\mathrm{ve}\end{array}$ \\
\hline $\begin{array}{l}\text { Cardiac glycosides: } \\
\text { Keller lilliani test } \\
\text { Baljet reaction }\end{array}$ & $\begin{array}{l}+\mathrm{ve} \\
-\mathrm{ve}\end{array}$ & $\begin{array}{l}-\mathrm{ve} \\
-\mathrm{ve}\end{array}$ & $\begin{array}{l}-\mathrm{ve} \\
-\mathrm{ve}\end{array}$ \\
\hline $\begin{array}{l}\text { Flavonoids: } \\
\text { NaoH test } \\
\mathrm{NH}_{4} \mathrm{OH} \text { test } \\
\text { ALCL }_{3} / \mathrm{UV} \text { test }\end{array}$ & $\begin{array}{l}\text { ++ve } \\
++v e \\
+v e\end{array}$ & $\begin{array}{l}+\mathrm{ve} \\
+\mathrm{ve} \\
+\mathrm{ve}\end{array}$ & $\begin{array}{l}\text { ++ve } \\
++v e \\
++v e\end{array}$ \\
\hline $\begin{array}{l}\text { Anthraquinones: } \\
\text { Borntrager's test }\end{array}$ & $+\mathrm{ve}$ & $-\mathrm{ve}$ & $+\mathrm{ve}$ \\
\hline $\begin{array}{l}\text { Tannins: } \\
\mathrm{FeCl}_{3} \text { test }\end{array}$ & $+\mathrm{ve}$ & $-\mathrm{ve}$ & $-\mathrm{ve}$ \\
\hline $\begin{array}{l}\text { Saponins: } \\
\text { Forth test }\end{array}$ & $+\mathrm{ve}$ & $-\mathrm{ve}$ & $-\mathrm{ve}$ \\
\hline $\begin{array}{l}\text { Carbohydrates: } \\
\text { Molish test }\end{array}$ & +++ ve & +ve & +ve \\
\hline
\end{tabular}


From Table (1), it's obvious that this plant contains very little cardiac glycosides while its high in flavonoids and carbohydrates. Other Constituents such as alkaloids and anthraquinones are present in slight quanties.

\section{Conclusion:}

From the literature review and the relatively larger size of its bulbs in these series of studies, it was anticipated that this plant could contain high alkaloidal and glycosidal levels, but from the phytochemical screening it showed no significant levels. The presence of flavonoids and starchy carbohydrates was noticeable. This paper could serve as a starting point for further investigation of the flavanoidal contents of the Dipcadi erythraeum plant.

\section{References}

1- The Plant List: Dipcadi erythraeum Webb \& Berthel. London: The Plant List, 2013.

2- STEDJE B. and NORDAL I.: Cytogeographical studies of Hyacinthaceae in Africa south of the Sahara. Nord J. Bot., 7: 53-65, 1987.

3- DEB D.B. and DASGUPTA S.: Revision of the genus Dipcadi Medik. (Liliaceae) in India and adjoining areas. Rec. Bot. Surv. India, 75: 50-70, 1976.

4- BOULOS L.: Flora of Egypt Checklist Revised. Annotated Edition. Cairo: Al Hadara Publishing, 2009.

5- EL HADIDI M.N. and FAYED A.A.: Materials for excursion flora of Egypt (EFE). Taeckholmia., 15: 182-9, 1994/1995.

6- EL-SHABRAWY M., MARZOUK M., KAWASHTY S., HOSNI H., EL GARF I. and SALEH N.: Flavonoid constituents of Dipcadi erythraeum Webb. \& Berthel. Asian Pacific Journal of Tropical Disease, 6 (5): 404-405, 2016.
7- MOUSSAID M., ELAMRANI A., BOURHIM N. and BENAISSA M.: [Contribution to the study of the essential oil of Dipcadi serotinum (L.) Medik of Morocco]. Afr. Sci. Revue Int. Sci. Technol., 9 (1): 34-42, 2013.

8- CHAUDHARY S.A.: Vegetations of the kingdom of Saudi Arabia, p. 610, 1999.

9- FIRBOWM DATHAN N.: Flora of Palestina, Vol. 4. pp. $57 \& 38,1986$.

10- MARZOUK M., ELKHATEEB A., ABDEL LATIF R., ABDEL-HAMEED E., KAWASHTY S. and HUSSEIN S: C-glycosyl flavonoids-rich extract of Dipcadi erythraeum Webb \& Berthel. bulbs: Phytochemical and anticancer evaluations. Journal of Applied Pharmaceutical Science, Vol. 9 (06): pp. 094-098, 2019.

11- RIZK A.M., HAMMOUDA F.M. and HUSSEIN L.: 21 st international horticultural congress (Hamburg, Germany Aug, 1982)

12- RIZK A.M. and HAMMOUDA F.M.: Ismail, S.I: Ghaleb, H.A. Girgis. Z.I: Planta Med., 45: 145, 1982.

13- RIZK A.M., AL NAJDY S.A. and EL MIS SIRY M.M.: Pharmazie, 37, 737, 1982.

14- BRAIN K. and TURNER T.D.: Practical Evaluation of phytopharmacenticals. Bristol., 1975.

15- BOULOS L.: Flora of Egypt, revised annotated edition. Al Hadara Publishing, Egypt, 2009.

16- ABDULKAREEM K.A., GARUBA T., ABDULRASAQ R. and MUSTAPHA O.T.: Studies on the morphology and phytochemical constituents of Dipcadi filamentosa in two states of North-Central Nigeria. J. Chem. Biol. Phys. Sci., 4 (3): 2158-64, 2014.

17- ADLY F., MOUSSAID M., BERHAL C., RAZIK A., ELAMRANI A.A., MOUSSAID H., BOURHIM N. and LOUTFI M.: Phytochemical screening and biological study of ethanol extractives of Dipcadi serotinum (L.) Medik. EJARBLS, 3 (3): 17-23, 2015.

18- ALI S.I.: Flora of Pakistan: Hyacinthaceae. Department of Botany, University of Karachi, Karachi, Pakistan, No. 214, 2005. 


\section{دراسة كيميائية نباتية لبصل الماء بصيل الماى}

بصل الماء أو بصيل الماى هو نبات يوجد فى كثير ممن البلدان العربية ويعرف فيها بأسماء مختلفة وهو نوع برى صالح للاكل ويستخدم عادة فى الطب الثعبى. الهدف من الدراسة: تم تصميم هذه الدراسة لإجراء فحص كيميائى نباتى مفصل للمكونات النشطة فى السيقان والأقداق والزهود من

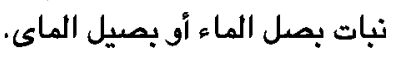

خطة البحث: تم إجراء الفحص الكيميائى النبات بصل الماء أو بصيل الماى بعد جمعه من صحارى كبد والأحمدى فى الكويت خلال ربيع عام ...

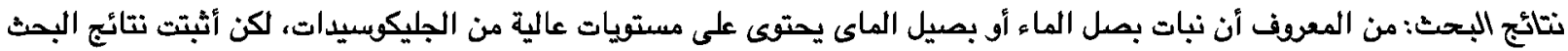

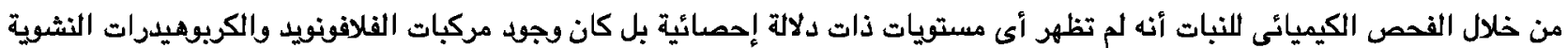
ملحوظاً. وأخيراً يمكن أن تكن نتائج هذه الدراسية بمثابة نقطة بداية لعمل المزيد من الفحص الكيميائى للتحقق من محتويات مركبات الفلافونويد

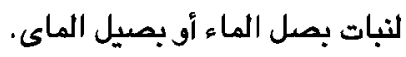

